\title{
JAN KOULA A PRVNÍ HISTORICKÁ A NÁRODOPISNÁ EXPOZICE NÁRODNÍHO MUZEA'
}

\section{LENKA MERGLOVÁ PÁNKOVÁ}

\section{ABSTRAKT/ABSTRACT:}

Jan Koula (1855-1919) byl výraznou osobností české národní kultury 19. století. Český architekt, pedagog a muž mnoha zájmů, který se zúčastnil soutěže na vytvoření návrhu budovy Národního muzea. Jeho projekt neuspěl, ale do muzea nastoupil v roce 1892 jako kustod. Stal se prvním ředitelem sbírky historické archeologie a národopisu, vybudoval první expozici těchto oborů. Byl velmi aktivní ve sbírkotvorné činnosti a spolupráci s muzejníky v Čechách, na Moravě i na Slovensku.

Jan Koula and the first historical and ethnographic permanent exhibition of the National Museum

Jan Koula (1855-1919) was a significant figure in the 19th century Czech national culture: Czech architect, pedagogue and man of many interests, who participated in the architectural competition for a new building of the National Museum. His project was not accepted, but he was employed in the museum as custodian since 1892 . He became the first director of the historical and ethnographic collection and built up the first permanent exhibition in these disciplines. He was very active in collectionbuilding and cooperation with

1 Příspěvek je jedním z výstupů Interního grantového projektu Západočeského muzea v Plzni č. IGP 2017/04. museum workers in Bohemia, Moravia and Slovakia.

\section{KLÍČOVÁ SLOVA/KEYWORDS:}

Jan Koula - architekt - etnograf Národní muzeum - 19. století Jan Koula - architect ethnographer - National Museum 19th century

Jan Koula (1855-1919) byl vzděláním architekt, po studiu v Praze a Vídni působil od roku 1880 na České technice (dnes ČVUT), kde postupně dosáhl docentury, profesury a $\mathrm{v}$ roce 1903 se stal dokonce jejím rektorem. Vedle výuky architektonické a ornamentální kresby, kterou vedl na stolici architektury, spolupracoval jako stoupenec historismu na četných projektech s Antonínem Wiehlem. Mezi jejich společné akce patří i účast $v$ soutěži na budovu Národního muzea (1883). Z celé řady Koulových návrhů nebylo realizováno mnoho; v mládí škola a sokolovna pro rodný Český Brod, vlastní vila ve Slavíčkově ulici v Praze Bubenči. V rámci asanace Prahy přišel s monumentální vizí propojení Václavského náměstí s Letnou prostřednictvím Staroměstského náměstí, Mikulášské (Pařížské) třídy, tzv. asanačního (Čechova) mostu a letenského průkopu. Vedle stavebních projektů vytvářel i svoje malé architektury; navrhoval nábytek, sklo, keramiku, šperky a textil. Vyvrcholením jeho designerské práce byla jídelna ve stylu české renesance, součást
https://doi.org/10.5817/MuB2020-1-4

instalace tzv. Českého interiéru pražské Obchodní a živnostenské komory na Světové výstavě v Paříži roku 1900. Další sférou, kde Jan Koula působil, byla činnost teoretika a znalce umění. Pohyboval se nejen mezi architekty a výtvarnými umělci, ale zasedal i v mnoha komisích, které rozhodovaly o kulturních projektech, inicioval akce na záchranu uměleckých památek. Jeho historické a národopisné vědomosti jej zavedly mezi sběratele a do mnoha muzeí, zájem o archeologii mezi archeology a historiky. Měl přehled o všem, co se na poli oficiální i neoficiální kultury v zemi dělo, cestoval po sbírkách a muzeích celé země, spolupracovníky našel nejen v Čechách a na Moravě, ale na četných místech na Slovensku. $S$ jejich pomocí a radou organizoval výstavy výšivek v osmdesátých letech a shromažd'oval informace o vzácných předmětech pro své Památky umělecko-průmyslové $v$ Čechách - první obrazovou edici mapující skvosty uměleckého řemesla od doby románské až do baroka v tuzemských sbírkách. Nejvýrazněji se projevila Koulova všestrannost při príipravách Jubilejní zemské výstavy v Praze roku 1891. Tehdy se stal členem výboru pro uspořádání přehledové Retrospektivní výstavy, která měla představit $\mathrm{v}$ pečlivém výběru „staré výrobky uměleckého průmyslu $v$ majetku českém“. ${ }^{2}$ Současně připravoval národopisnou

2 KOULA, Jan. Naše jubilejní výstava, VI. oddělení retrospektivní. Osvěta, 1891, roč. XXI, s. 946. 
expozici v České chalupě společně s Kroužkem České chalupy, kam mimo jiné náležel i Josef Ladislav Píč. Ten společně $s$ jednatelem správního výboru Musea království Českého Josefem Emlerem Koulu po úspěchu České chalupy oslovil a vybídl ke vstupu do muzea na funkci kustoda. Ke Koulovu prvnímu profesionálnímu kontaktu $s$ muzeem však došlo již dřive. V roce 1889 bylo při hloubení základů domu v Praze Na Bojišti objeveno a poté do sbírek muzea předáno několik sakrálních předmětů. Koula spolupracoval na jejich určení, vyhotovil kresby a popisy nejvzácnějších kusů pro další publikování. Ve svých pamětech tento kontakt označuje za počátek vztahu $\mathrm{k}$ muzeu a jeho sbírkám. ${ }^{3}$

Roku 1892 započala zcela nová etapa ve vývoji tehdejšího Národního muzea. Byl zahájen přesun sbírkových předmětů z Nostického paláce Na prríkopě do nové budovy na Václavském náměstí, kde bylo potřeba uspořádat zejména velkou archeologickou sbírku. S příchodem Josefa Ladislava Píče a Jana Kouly došlo k rozdělení sbírky na dvě části, na archeologii prehistorickou, jíž se ujal archeolog Josef L. Píč, a archeologii historickou, kterou převzal Koula. Ten se měl v budoucnu postarat i o teprve se rodící sbírku národopisnou. Při jeho nástupu do muzea čítala celých sedm (!) kusů. Sbírkové předměty přebíral nový kustod za výjimečné situace. Po založení muzea se přijímaly památky překotně a bez jakéhokoliv evidenčního systému. Celou sbírku poprvé ujednotil historik Jan Erazim Vocel, soupis vyhotovil muzejní asistent Jan Hlavatý a seznam předmětů byl

3 KOULA, Jan E. O tatínkovi. Vzpomínky. Rukopis, 1965, s. 88. (Soukromý majetek). Zprávu o nálezu a předání do muzea s podrobným popisem přinesly Národní listy, 1889, roč. XXIX, č. 188, 10. 7. 1889, s. 3. Předměty Koula zachytil na akvarelech, které byly reprodukovány ve Zlaté Praze, 1889, roč. VI, s. 419. v roce 1863 publikován v muzejním průvodci. O něj se opíral Jan Koula při převzetí sbírky v roce 1892 , aby mohl přistoupit $k$ roztrrídění předmětů podle materiálu, slohu a doby pro účely nově vznikající expozice.

Lhůta $\mathrm{k}$ přestěhování do nové budovy na Václavském náměstí byla velmi krátká, přičemž pro historickou archeologii a národopis nebyl zatím určen ani způsob vystavení, ani typ vitrín. Koncem února byl Koula jmenován kustodem, $v$ dubnu převzal veškeré sbírky a rovnou přikročil ke stěhování. V květnu bylo vše přemístěno a prozatímně uloženo v původních skříních, protože $\mathrm{v}$ nové budově nebyly zř́izeny žádné depozitáře. Do července si Koula naplánoval způsob vystavení a druh vitrín a po jejich dodání do nich ihned instaloval vyčištěné sbírkové předměty, aby staré skříně mohly být postupně odstraněny. ${ }^{4}$ Samotná instalace probíhala od dubna následujícího roku a do svátku sv. Jana Nepomuckého v květnu bylo sestaveno celé oddělení zbraní, ${ }^{5} \mathrm{v}$ průběhu léta a podzimu se dokončovaly instalace keramiky, skla, železných, bronzových a zlatých památek a předmětů $\mathrm{z}$ dalších drahých materiáli̊. Pro vystavení se připravovala i sbírka hudebních nástrojů, které

\footnotetext{
4 KOULA, Jan. O vývoji historického oddělení musea král. Českého. Sbírka histor. archaeologická. Památky archaeologické a místopisné, 1904, roč. XXI, s. 30. Sám Koula o počátku budování expozice říká: „Vše obstaral jsem si sám bez jakýchkoliv porad s kýmkoliv vůbec. Stanovil jsem si vše pevně a definitivně, ač se jednalo opravdu o věc nikoliv snadnou. Nikdo z výboru musejního mi do toho nezasahoval, nebylo komisí, nebylo rozkladů, nebylo námitek. Co jsem chtěl, co jsem předložil, bylo přijato a hned také navrženo k provedení. Proto také to úžasné tempo, se kterým se vše dálo. Bylo $v$ tom opojení a radost z práce, která mne na vrchol těšila." Viz KOULA, Jan E. O tatínkovi. Vzpomínky. Rukopis, 1965, s. 82. (Soukromý majetek).

5 Oblíbeným termínem pro zahajování pražských výstav byl den zasvěcený sv. Janu Nepomuckému, kdy do města přijíždělo velké množství mimopražských návštěvníků. V tento svátek byly otvírány i nové expozice Národního muzea.
}

musely projít nejen čištěním, ale i restaurováním. ${ }^{6}$

Archeologické sbírky si postupně nacházely svoje místo v prvním poschodí nové budovy muzea. Přímo s Panteonem muzea sousedil sál se starými rukopisy a tisky, za ním následovala místnost s mincemi a medailemi. Ve třech výstavních sálech s výhledem do Jungmannovy třídy vystavil Josef L. Píč svoji prehistorickou kolekci. Expozici historickou od prehistorické archeologie dělila nárožní místnost, tzv. pavillon, který byl Koulovou chloubou. Osobně se totiž zasloužil o získání veškerého jejího vybavení. Šlo o „(...) dvě starožitné lékárny s laboratoři, první ze 17. století původem z kláštera Kapucínů na Hradčanech a druhá z lékárny U zlaté koruny na Malém náměstí Staroměstském \% 18. století“".7

Zachráněno a soustředěno sem bylo také množství lékárnického nářadí a nádobí z doby od 17. do 19. století. Do první místnosti zadního traktu muzea Koula nainstaloval celou historickou sbírku. Vedle zbraní, nábytku, hudebních nástrojů či uměleckých děl z nejrůznějších materiálů sem postupně umístil i obsáhlou kolekci církevního umění. V roce 1899 se totiž Jan Koula účastnil významného aktu předání kolekce církevních starožitností od Křestanské akademie a stál u vzniku církevního odboru v rámci oddělení historické archeologie. Jeho nejbližšími spolupracovníky na poli církevního umění se stali Antonín Podlaha

\footnotetext{
6 Valné shromáždění Společnosti musea roku 1894. Časopis Musea království Českého, 1894, roč. LXVIII, s. 36.

7 „(...) nádoby ze staré lékárny kapucínské $v$ pražské Loretě na Hradčanech, v době Marie Terezie zrušené a dosud i s léky venkoncem zachované", pokračuje Jan Koula v poznámkách o vývoji majoliky v Čechách, viz KOULA, Jan. Komentár k a avarelovým tabulím. Rukopis, 1919, nestr. (Soukromý majetek). Dále také Průvodce sbírkami Musea království Českého v Praze. Praha, 1905, s. 79; KOULA, Jan E. O tatínkovi. Vzpomínky. Rukopis, 1965, s. 89. (Soukromý majetek); Valné shromáždění Společnosti musea roku 1896. Časopis Musea království Českého, 1896, roč. LXX, s. 44.
} 
a Eduard Šittler. V souvislosti se vznikem církevního odboru předal Jan Koula muzeu i vlastní sbírku starého církevního umění. ${ }^{8}$

V pořadí devátá síň prvního poschodí nové budovy muzea měla být vyhrazena pro vystavení „národopisných sbírek českého lidu“.9 Členové Kroužku České chalupy učinili již v prosinci 1891, po skončení Jubilejní zemské výstavy, muzeu nabídku, že jeden muzejní sál zařídí jako Českou síň a naplní ji národopisnými památkami. Nabídku správní výbor muzea přijal ještě před Koulovým př́ichodem do muzea a určil k tomuto účelu sál v prvním patře naproti schodišti, tzv. dvoranu. Koncem roku 1892 navrhl architekt Koula pro tuto prostoru způsob vystavení a vlastní typ vitrín, které byly objednány a dodány v následujícím roce. Koula se pak ujal vedení prací na úpravě sálu za velké podpory členů komitétu České chalupy i dalších, zejména regionálních spolupracovníků. ${ }^{10} \mathrm{Na}$ počátku roku 1893 společně se svými spolupracovníky protřídil materiál a do menších vitrín umístil výšivky ze všech etnograficky významných koutů Čech společně s dalšími lidovými uměleckými díly ze dřeva, kovu a pracemi hrnčířskými či zlatnickými.

Do velkých pokojových vitrín byly nainstalovány interiéry, včetně částí architektury a nábytkové výbavy, které pomohly vytvořit

8 KOULA, Jan. O vývoji historického oddělení musea král. Českého. Sbírka histor. archaeologická. Památky archaeologické a místopisné, 1904, roč. XXI, s. 34 . Z venkovských kostelů byla stahována nejcennější paramenta a preciosa výměnou za nová, zhotovená dílnami Křestanské akademie nebo Paramentního ústavu. J. Koula a E. Šittler předali muzeu po roce 1899 i vlastní soukromé sbírky starého církevního umění.

9 Průvodce sbírkami Musea království Českého v Praze. Praha, 1905, s. 94.

10 KOULA, Jan. O vývoji historického oddělení musea král. Českého. Sbírka histor. archaeologická. Památky archaeologické a místopisné, 1904, roč. XXI, s. 33.

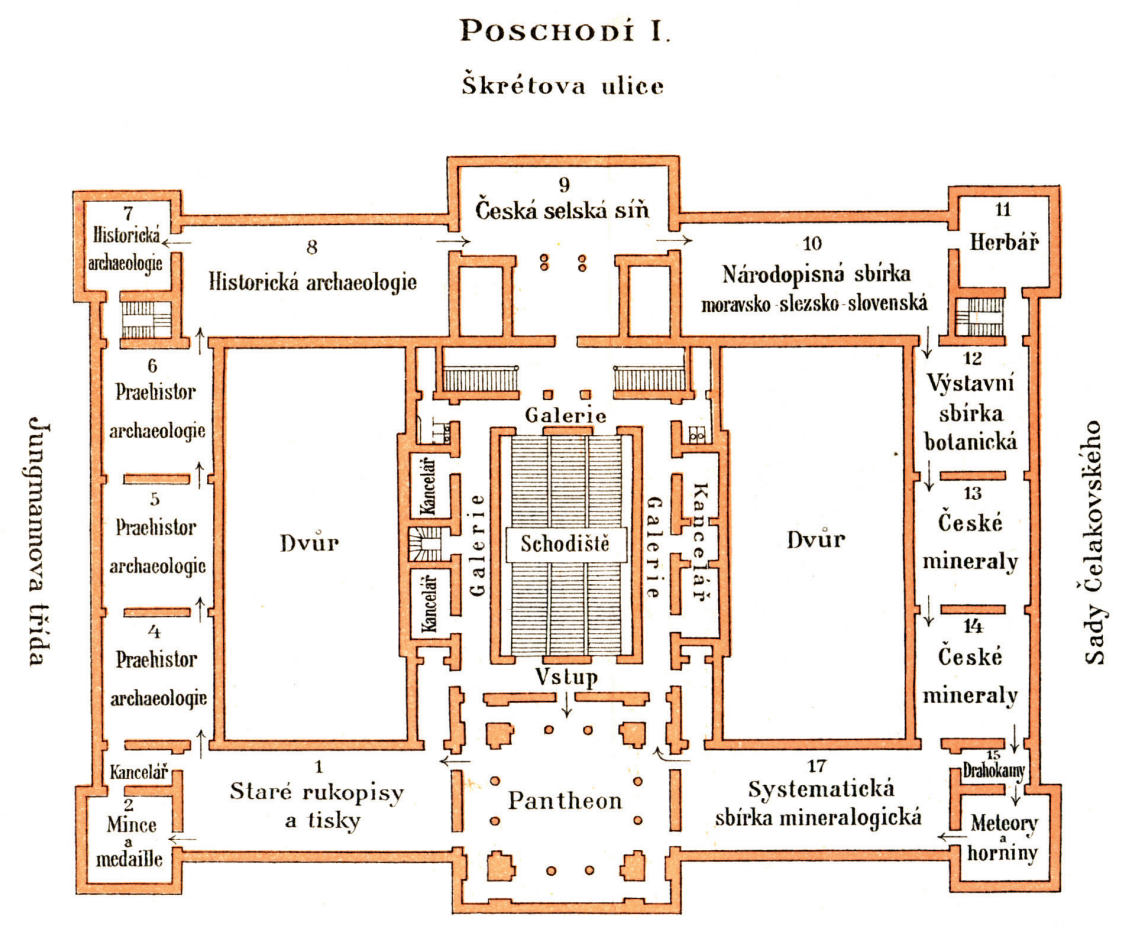

Sv.Václavské námèsti

Obr. 1: Plánek prvního patra budovy Musea království Českého (Průvodce sbírkami Musea království Českého v Praze. Praha, 1905, př́loha.)

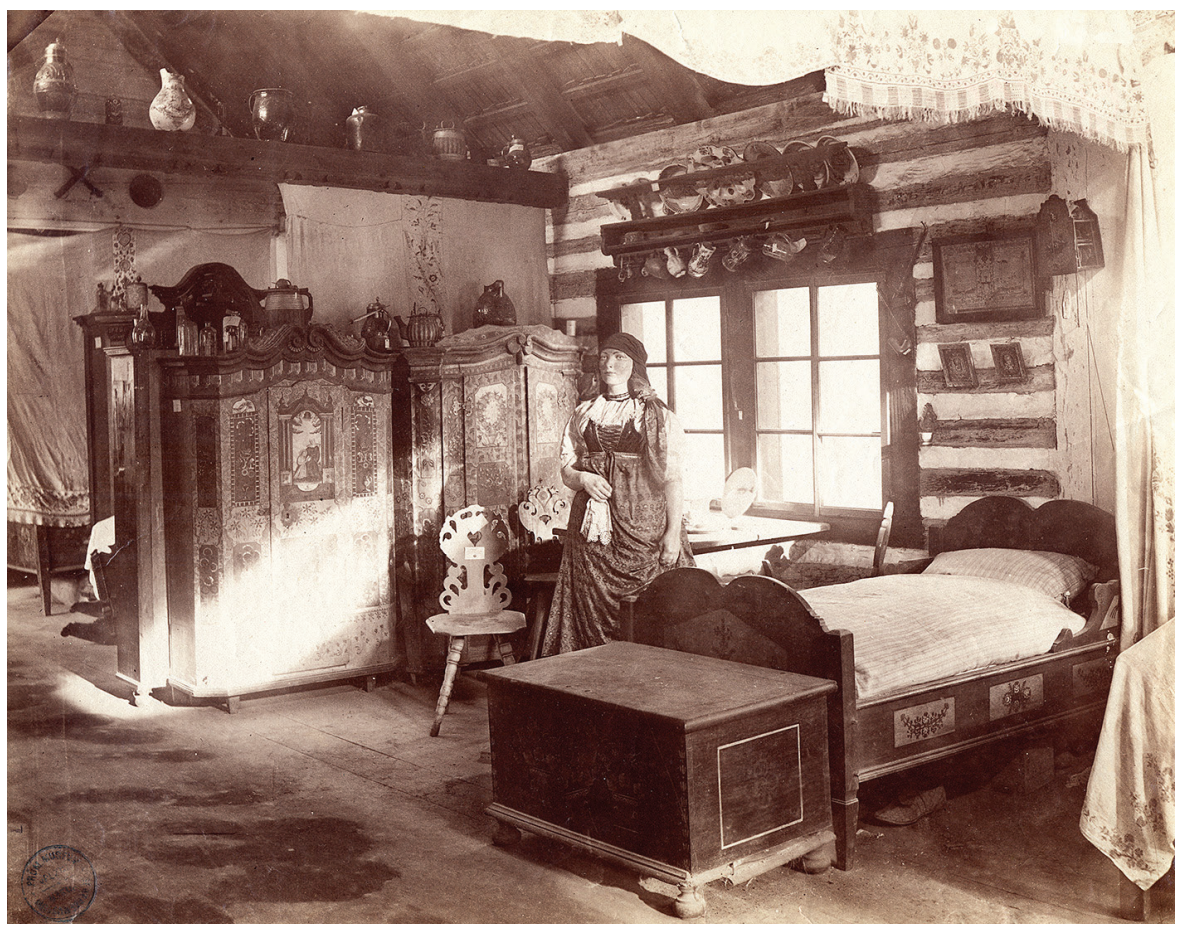

Obr. 2: Světnice z Litomyšlska, interiér z České chalupy. Jubilejní zemská výstava v Praze, 1891 (Anonym, 1891, albuminový papír na lepence, 19 × 23,7 cm. Západočeské muzeum v Plzni.) 
atmosféru pro figuríny $\mathrm{v}$ krojích prezentujících jednotlivé české kraje. Vitrínu tzv. Plzeňskou pomohli Koulovi uspořádat učitel J. Seitz a paní Tylová z Ejpovic, po ní následovala vitrína Středočeská a Východočeská. U vitríny Litomyšlské přispěla radou i hmotnými dary spisovatelka a nadšená etnografka Teréza Nováková, vitrínu Blatskou vybavil František Lego, kustod muzea v Jindřichově Hradci. ${ }^{11} \mathrm{~S}$ menším časovým odstupem byly uspořádány ještě vitríny Severočeská a Domažlická. Zajímavá a na předměty z Chodska bohatá vitrína vznikla díky darům a nákupům od Ondřeje Sweinara, řídícího učitele v Postřekově v dubnu 1894. Obecně výšivky, kroje, nábytek i veškerá výbava vitrín muzejní expozice pocházely $\mathrm{z}$ darů a náklady spojené $s$ přípravou České síně uhradil zmíněný komitét. ${ }^{12}$

Po úspěšné realizaci České síně požádal Kroužek České chalupy muzeum ještě o jednu místnost, kterou zamýšlel vybavit památkami z Moravy, Slezska a Slovenska. Desátá sín prvního patra muzea nevznikla najednou. První část sestávající ze tři vitrín (Lanžhotská, Hanácká, Kyjovská) Koula dokončil už v dubnu roku 1895, ale pokračoval ještě do roku 1898, kdy nainstaloval vitríny z Hrozenkova, Slezska a Slovenska. V dokončené síni pak mohli návštěvníci vidět třeba postavy svatebčanů z Lanžhota před bohatě malovaným žudrem, dvojici z Ratíškovic u Kyjova v kroji s bohatým černým vyšíváním nebo ženu z Pieštan oděnou v oplecku spolu s děvčetem z Bošácké doliny a šohajem z Detvy. Nechybělo ani starožitné vyšívání valašské a čičmanské, muž v krpcích z Hrozenkova, dívky

11 Valné shromáždění Společnosti musea roku 1894. Časopis Musea království Českého, 1894, roč. LXVIII, s. 37.

12 Valné shromáždění Společnosti musea roku 1895. Časopis Musea království Českého, 1895, roč. LXIX, s. 36.

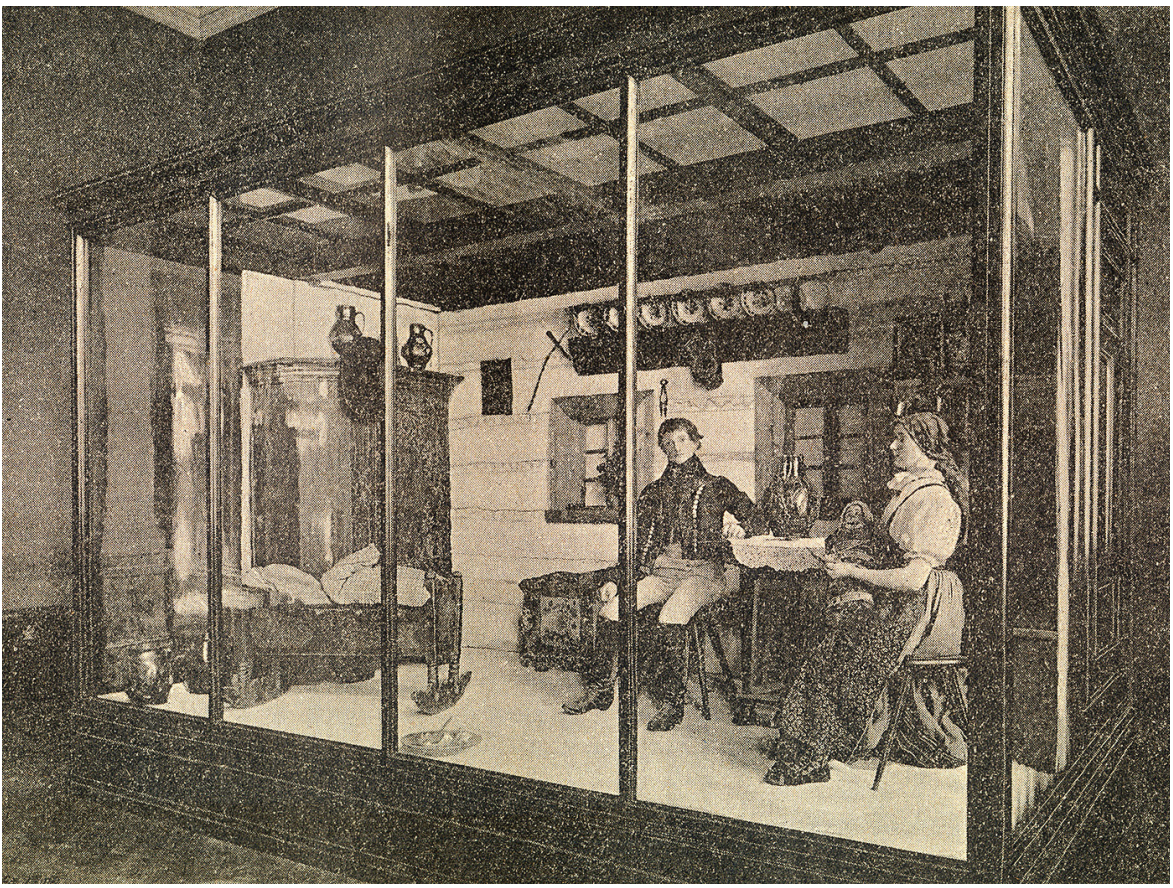

Obr. 3: Světnice z Litomyšlska, Česká selská síň Musea království Českého (Český lid, 1893, s. 643.)

v krojích od Těšína či Trenčína. ${ }^{13}$ Vedle figurín, architektury a nábytku obsahovaly vitríny také řadu národopisných zajímavostí. Při budování této části expozice Koula vycházel ze svých zážitků $\mathrm{z}$ cest po Slovensku a Slovácku, z fotografií, které pořídil společně s Josefem Šímou st. a Josefem Klvaňou. ${ }^{14}$ Řadu sbírkových předmětů nakoupil pro muzeum díky spolupráci se slovenskými národními buditeli a etnografy, např́klad Andrejem Kmetěm a Josefem L'. Holubym. ${ }^{15}$ Mezi nejzajímavější předměty patřily vedle výšivek i „slovácké majoliky“ z 18. a 19. století z jihu Moravy a ze Slovenska. „Nádoby tyto vynikají rázovitou ornamentikou, vztahují se $k$ pořádkům a cechům řemeslným.

13 Průvodce sbírkami Musea království Českého v Praze. Praha, 1905, s. 100.

14 J. Šíma st. (1851-1929), architekt, etnograf, fotograf; J. Klvaňa (1857-1919), přírodovědec, pedagog, etnograf z Uherského Hradiště. Společně s J. Koulou procestovali a dokumentovali etnograficky zajímavá místa na Moravě a Slovensku v 80. a 90. letech.

15 Andrej Kmet' (1841-1908), slovenský archeolog, geolog, etnograf; Jozef L'udovít Holuby (1836-1923), evangelický farář, slovenský etnograf.
Majolika ta se zove z části i habánskou, nejvíce vyráběnou v Modré, Sobotišti, (...) Dehtici, Stupavě a Holiči."

Obě místnosti s národopisnou tématikou nejsou jen dokladem zájmu o lidovou kulturu, ale představují velký přínos a novátorství v muzejní instalaci a prezentaci. První velké vitríny jsou nainstalovány již v květnu 1893 a oba sály zpřístupněny (sice ještě ne zcela dokončené) v květnu roku 1895. Návštěvníci muzea se tedy mohou seznámit s lidovými interiéry ještě před započetím Národopisné výstavy českoslovanské.

V tomto druhu činnosti neměl Koula vyjma spolupráce s Josefou Náprstkovou žádné české vzory ani předchůdce. Při vytváření interiérů pro expozici Národního muzea vycházel pouze $\mathrm{z}$ vlastní zkušenosti nabyté při realizaci interiérů České chalupy a výstav

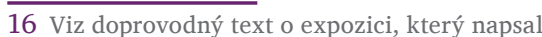
J. Koula a B. Matějka. Průvodce sbírkami Mused království Českého v Praze. Praha, 1905, s. 98. 
výšivek. Poučení tehdy jistě plynulo $\mathrm{z}$ expozic světových výstav a nově vznikajících přírodovědných muzeí, ${ }^{17}$ i když chalupa se zrodila bez dlouhodobého předběžného plánu, improvizovaně, během několika měsíců, a to jen díky velkému nasazení všech členů Kroužku České chalupy. ${ }^{18}$ Všem pochybením, kterých se přípravný tým České chalupy dopustil, se podařilo Janu Koulovi při př́ípravě muzejní expozice vyvarovat. ${ }^{19}$ Vedle architektonického návrhu zcela novátorských a originálních „světnicových vitrín“ připravoval i projekty částí rázovitých lidových staveb, které používal $\mathrm{k}$ dokreslení venkovské atmosféry. Zcela původní byla také myšlenka figurín oblečených do regionálních krojů. Jejich těla i tváře byly modelovány podle fotografií, na nichž Koula a jeho spolupracovníci zachytili typické obyvatele jednotlivých regionů. ${ }^{20}$ Fyziognomií se měly odlišovat stejným způsobem,

17 Instalace podobného rázu bylo možné zhlédnout již v rámci světových výstav ve Vídni roku 1873 či v Paříži 1878. Ve stejném roce jako Česká chalupa (1891) vzniklo ve Skansenu u Stockholmu legendární muzeum v přírodě vybavené figurínami.

18 Kroužku předsedal A. Jirásek, mezi členy patřili vedle Kouly a J. L. Píče i etnograf Č. Zíbrt či znalkyně lidového umění R. Tyršová. Ještě v lednu 1891 nebylo zcela jasné, zda chalupa zapadá do celkového konceptu výstavy. Teprve v březnu byl ustanoven Výbor pro výstavu lidového umění v Čechách. Tento tzv. Kroužek České chalupy oslovil regiony a teprve v dubnu začaly docházet první zásilky. Sto let práce. Praha, 1891, s. 114, 117.

19 Nedostatek materiálu z některých regionů byl v České chalupě vyřešen náhradou z regionů jiných. Koula se v muzeu snažil zajistit originální materiál z každého regionu úzkou spoluprací s místními odborníky. Dosvědčuje to řada dopisů, které se věnují i nejmenším detailům v instalaci.

20 Na Světové výstavě ve Vídni roku 1873 byl soubor moravských krojů vystaven na figurínách, vytvořených sochařem Adolfem Loosem st., otcem legendárního architekta. Viz WINTER, Tomáš a Pavla MACHALÍKOVÁ (eds.). Jdi na venkov! Výtvarné umění a lidová kultura $v$ českých zemích 1800-1960. Revnice: Arbor vitae societas - Praha: Artefactum, 2019, s. 136. Tuto koncepci Koula (vědomě?) převzal a zdokonalil. Modelování figurín nebylo ostatně jediným příkladem využití Koulových fotografií. Rázovitých postav v krojích, které Koula fotografoval v Nové Vsi a Zarječí v letech 1887-1889 využil i V. Hynais jako předloh pro plakát k Národopisné výstavě českoslovanské roku 1895. Podrobněji MERGLOVÁ PÁNKOVÁ, Lenka a Jan MERGL. Jan Koula jako se různí temperamentem i lid v jednotlivých krajích země. Figuríny podle Koulova záměru modeloval sochař Antonín Popp a Koula je přri instalaci ještě osobně koloroval. ${ }^{21}$ Zkušenosti pro instalační práce $\mathrm{v}$ muzeu přinesla i Koulova spolupráce na př́ípravě českého pavilonu pro Mezinárodní výstavu ženských umění v Paříži roku 1892. Pro tuto př́ležitost navrhl drobnou stavbu k umístění do prostoru výstavního sálu, jejíž bílé stěny oživovala malba lidových motivů v barvě modré a červené. ${ }^{22}$ I zde Koula k instalaci krojů a výšivek využil Poppovy kolorované figuríny, které však byly umístěny vně vitrín.

Práce na instalaci druhé národopisné síně Koula ukončil $\mathrm{v}$ roce 1898, ale $\mathrm{z}$ nedostatku jiného prostoru bylo po čase nezbytné jednotnou národopisnou kompozici narušit a umístit sem i další etnografické oblasti. Postupně přibyly „zde prozatímně vyloženy kollekce starožitností mexických a peruánských (...) vysoce cenné umělecké práce čínské, japonské a indické“. ${ }^{23}$

\section{Na přelomu století už začíná} v muzejní budově boj o poslední

novorenesančník a vlastimil. Plzeň: Západočeské muzeum v Plzni, 2019, s. 137.

21 „Namaloval jsem mu pěknou hlavu, figurka je opravdu rozkošná - i v pohnutí se mi pak zdařila, popisuje Koula dohotovení Poppových figurín pro vitrínu z Litomyšle $\mathrm{v}$ dopise Teréze Novákové z konce roku 1892. Literární archiv památníku národního písemnictví v Praze (dále jako LA PNP), fond T. Nováková.

22 Výzdobu vitrín podle Koulových návrhů realizovala při jejich sestavování přímo v Pař́iži Zdenka Braunerová. Koula byl jedním z prvních, kteří pracovali s lidovým motivem, popularizovali lidovou kulturu a byl za to kladně oceňován dobovými kritiky (zejména Č. Zíbrtem a R. Tyršovou).

23 Valné shromáždění Společnosti musea roku 1894. Časopis Musea království Českého, 1896, roč. LXX, s. 45; Průvodce sbírkami Musea království Českého v Praze. Praha, 1905, s. 101. Např́iklad vyšívaná japonská a čínská roucha, dar od stavebního rady J. Hlávky z let 1902-1903, jehož přijetí Koula osobně vyřizoval, byl podmíněn trvalým vystavením v expozici. Nakonec byl dar umístěn v pozadí národopisného sálu č. 10 společně $s$ předměty $\mathrm{z}$ Tichomoří. LA PNP, fond J. Hlávka. Nedatované dopisy J. Hlávkovi. zbytky místa. Nedostatek výstavního prostoru je řešen přidáváním menších vitrín, ale i tak se jeví situace bez radikálního zásahu neřešitelnou. $\mathrm{V}$ roce 1898 jsou nově pro potřeby muzea zapůjčeny prostory bývalého Retrospektivního pavilonu na pražském výstavišti, kam se postupně přesouvají větší architektonické články, části staveb získaných většinou z archeologických výzkumů. Pronájem v Retrospektivní budově zajistil po skončení Výstavy architektů a inženýrů asistent historické archeologie Bohumil Matějka, který nastínil i koncepci budoucího Lapidária Národního muzea. ${ }^{24}$ Po Matějkově odchodu $\mathrm{z}$ muzea $\mathrm{v}$ roce 1904 Jan Koula navázal na jeho myšlenku, Lapidárium dobudoval a $\mathrm{v}$ roce 1908 otevřel pro veřejnost. I přes toto významné odlehčení se ukázalo, že budova muzea není pro množství sbírkových předmětů, které sem směřovalo, dostatečná. Potvrdilo se, že při plánování stavby architekt či zadavatel zcela opomněli potřebu zázemí, pomocných místností a skladišt́. Jedním z možných a diskutovaných řešení byl přesun národopisné sbírky do Náprstkova muzea, z něhož se mělo stát „embryo velkého muzea cizokrajné etnografie“. ${ }^{25}$ Josef L. Píč se v tomto ohledu mnohokrát zastával Koulovy národopisné části muzea, a vždy se stavěl proti vypuzení sbírky lidového umění, na jejíž obhajobu uváděl, „že by byl ochoten přistoupit jedině na přeložení národopisu cizokrajného, protože památky našeho selského lidu

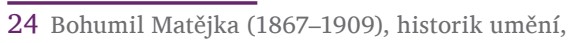
spisovatel, od roku 1904 vážně nemocný.

25 SKLENÁŘ, Karel. Archeolog Josef Ladislav Píč jako muzejník v Národním muzeu. Časopis Národního muzea, 2013, roč. CLXXXII, s. 77. Botanik L. J. Čelakovský, kustod botanické sbírky, navrhoval dokonce svolat muzea a reorganizovat celé muzejnictví. V té době se konaly porady pražských muzeí, ale podle svědectví Č. Zíbrta rozpravy k ničemu nevedly, protože každé muzeum hájilo své zájmy a svůj program. 
patří do muzea našeho spíš, než opelichaní indiáni““. ${ }^{26}$

I proto se Jan Koula od roku 1910 usilovně zabýval myšlenkou na rozšíření budovy na Václavském náměstí a posléze vypracoval podrobný plán přístavby, která by citlivě navázala v konstrukčním i výzdobném principu na původní stavbu architekta Josefa Schulze. Mínil vybudovat postranní křídlo směrem do parku a vytvořit tak nový depozitní prostor. Dokončený plán předložil roku 1913 správnímu výboru muzea, který vyslovil slova díků, ale zároveň nezastíral pochybnost, že by se snad „přistavba mohla uvésti ve skutek“. ${ }^{27}$

Koula, stejně jako Píč, měl vedle práce kustoda i své pravidelné zaměstnání. Jako vysokoškolský učitel na České technice se z časových důvodů musel po vstupu do muzea vzdát dalších činností, významně omezil práci architekta a trávil v muzeu 3-4 hodiny denně. ${ }^{28}$ Otevření první části expozice sice proběhlo v květnu roku 1893, ale teprve $\mathrm{v}$ červenci toho roku předal Jan Harrach, prezident Společnosti Musea království Českého Josefu Píčovi kancelář a laboratoř v přízemí budovy. Kancelář v blízkosti výstavních sálů sloužila jako pracovna nejen Píčovi, ale také Janu Koulovi, který vlastní pracovnu vůbec neměl a potřeboval zázemí při práci na expozici. Laboratoř a dílna

\footnotetext{
26 Tamtéž, s. 70.

27 KOULA, Jan E. O tatínkovi. Vzpomínky. Rukopis, 1965, s. 86. (Soukromý majetek). Koulův plán počítal s přístavbou lichoběžníkového půdorysu, která by přiléhala $\mathrm{k}$ původní budově v místě jejího jižního nároží a vybíhala do Celakovského sadů podél Škrétovy ulice. $S$ původní muzejní budovou měla být propojena obloukem chodby, který by mezi starou a novou stavbou vytvořil uzavřený dvůr. Výškou i rozvrhem fasády Koula kopíroval Schluzovu budovu včetně nárožních věží. Návrh z roku 1912, viz Archiv architektury a stavitelství Národního technického muzea v Praze, fond č. 22 Jan Koula.

28 Na technice vyučoval Jan Koula 24 hodin týdně. LA PNP, fond $J$. Hlávka. Nedatovaný dopis J. Hlávkovi.
}

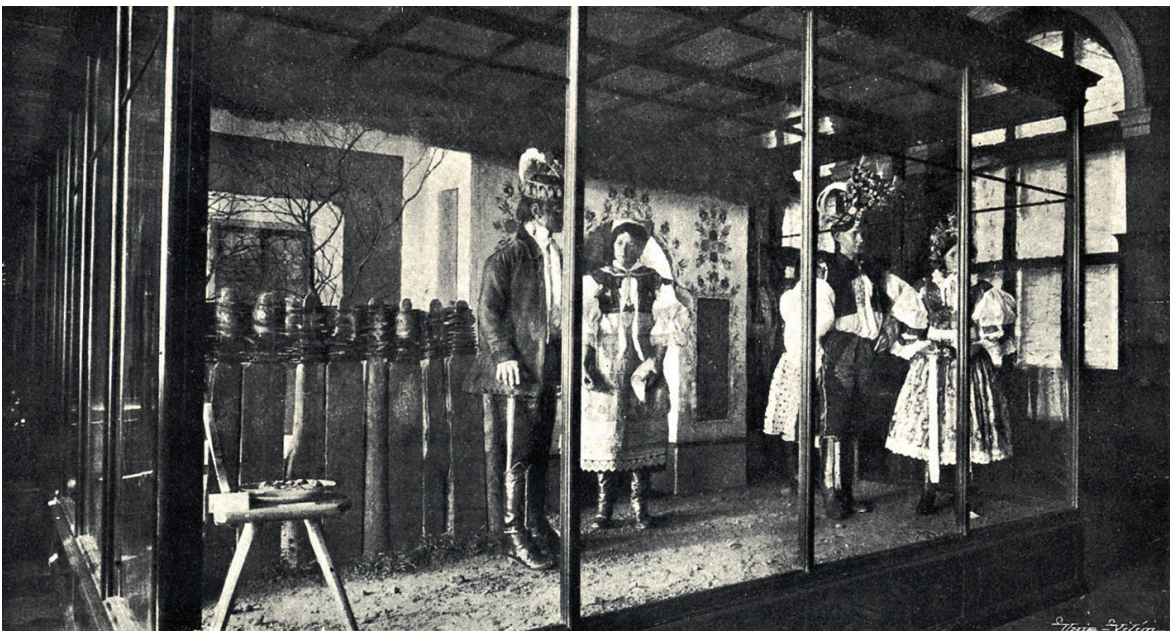

Obr. 4: Světnice Lanžhotská. Síň Moravská, Slovenská a Slezská. Expozice Musea království Českého (Průvodce sbírkami Musea království Českého v Praze. Praha, 1905, s. 68.)

v přízemí byla také společná pro celé archeologické oddělení. Oba kolegové kladli velký důraz na roli fotografie v moderní vědě, jež byla důležitá jak z pohledu archeologa, tak z pohledu národopisce.

Prosazovali proto zřízení společné fotodílny a v roce 1894 získali dokonce povolení zakoupit vlastní fotoaparát. ${ }^{29}$ Spolupracovali spolu také při vydávání muzejního časopisu Památky archeologické a místopisné. Píč byl jejich hlavním redaktorem již od roku 1887, Koula se stal spoluredaktorem Památek roku 1906. Společně zavedli do periodika vědeckou fotografii.

Až do Píčovy tragické smrti roku 1911 byla muzejní práce Jana Kouly bezvýhradně uznávána. ${ }^{30}$ Pak se mezi Janem Koulou a správním výborem muzea nahromadily problémy, které obě strany neměly sílu řešit. Po Koulově

29 SKLENÁř, Karel. Archeolog Josef Ladislav Píč jako muzejník v Národním muzeu. Časopis Národního muzea, 2013, roč. CLXXXII, s. 69. Fotoaparátu zřejmě využívalo spíše oddělení prehistorické archeologie při pracích v terénu, protože Koula měl svůj vlastní fotoaparát již nejpozději od roku 1887 a své publikace či články doprovázel vlastními fotografiemi, případně ilustracemi.

30 KOULA, Jan E. O tatínkovi. Vzpomínky. Rukopis, 1965, s. 85. (Soukromý majetek). „Až do smrti prof. Píče byla práce tatínkova v museu plně uznávána. Pak nastaly boje stran a interesů $a v$ těch neponechána ani má osoba stranou“, komentuje a cituje otce ve svých vzpomínkách Jan E. Koula. vážné nemoci a dílčích neshodách $\mathrm{v}$ roce 1912 rezignoval na místo ředitele sbírek. ${ }^{31}$ Jedním $\mathrm{z}$ důvodi̊ byl i požadavek výboru opatřit sbírkové předměty vedle českých i německými popisy. Jan Koula se v této choulostivé otázce odvolával na slib, který komitét České chalupy dal všem mecenášům, spolupracovníkům a dárcům lidového umění, že předměty nikdy nebudou označeny jinak než česky. Když mu to pak bylo za války úředně nařízeno, odešel z muzea definitivně.

Dodnes zůstává otázkou, jestli skutečný důvod Koulova odchodu nebyl složitější a co vše mohlo stát za neshodami se správním výborem muzea. ${ }^{32}$ Po čtvrt století

31 Ředitelem byl jmenován roku 1905 za zásluhy o zvelebení muzejních sbírek. Archiv Národního muzea v Praze, Registr Národního muzea, kart. 64. Protokol ze schůze správního výboru 10. 7. 1905.

32 V pestrých aktivitách Jana Kouly bychom mohli dnešní perspektivou nalézt střet zájmů. Byl členem kuratorií řady muzeí, Jednoty pro dostavbu chrámu sv. Víta, členem komisí pro rekonstrukci Karlštejna a dalších staveb, ale současně měl vlastní sbírku a s uměleckými předměty obchodoval. Jako tvůrce kresebné dokumentace Svatovítského pokladu a památek nalezených při dostavbě katedrály sv. Víta na Pražském hradě a při rekonstrukci hradů Zvíkova a Karlštejna měl během prací na kresbách neomezený prrístup do katedrály, královské hrobky, i na další objekty. Je známo několik odkazů na textilie, šperky, keramiku, které získal při archeologických nebo restaurátorských pracích a později je vystavil (např́iklad na 
Koulovy muzejní práce nezůstal v archivu ústavu téměř žádný doklad o jeho činnosti, natož připomínka $\mathrm{v}$ podobě osobního archivního fondu. ${ }^{33}$ At už ale byly spory a důvody jakékoliv, Koula zůstává do historie muzea zapsán natrvalo mnoha svými zásadními a mnohdy zcela novátorskými činy. Svými zkušenostmi znalce užitého umění přispěl ke zhodnocení sbírek, mnoho předmětů pomohl určit a identifikovat. Publikační činností popularizoval sbírku historické archeologie a zasadil se rovněž o nový pohled na užité umění v rámci celé umělecké tvorby. Kontakty a spoluprací $\mathrm{s}$ řadou významných a zkušených muzejních pracovníků získával doplňující informace o kolekci, kterou spravoval. Zkušenosti z praxe architekta, který se aktivně podílel na přípravě mnoha expozic a výstav (Jubilejní zemská výstava v Praze roku 1891, Národopisná výstava českoslovanská 1895 , Výstava architektury a inženýrství 1898, Světová výstava v Paříži 1900 a řada dalších), dokázal využít při úkolech pro Národní muzeum, at už šlo o stálou expozici a návrhy originálních světnicových vitrín nebo při organizování Lapidária. ${ }^{34}$ Zcela výjimečná je jeho role znalce

Retrospektivní výstavě), publikoval nebo daroval do sbírek muzea. Vedle toho však odprodal muzeu soubor zlatých a stříbrných gotických prstenů a devocionálií v době, kdy současně byl i jeho kustodem. Původ předmětů naznačují dva fragmenty gotických textilií z katedrály sv. Víta, které muzeu daroval. Více STEHLÍKOVÁ, Dana. Waldes a ti druzí. Pražští sběratelé klenotů a obchodníci. In Sborník semináre k 100. výročí otevření Waldesova muzea. [Jablonec nad Nisou] Muzeum skla a bižuterie v Jablonci nad Nisou Praha: Kotěrovo centrum architektury, 2018, s. 26-31. Jiný názor na původ textilií však uvádí např́íklad Antonín Podlaha. Viz PODLAHA, Antonín a Eduard ŠITTLER. Památky po sv. Václavu. Památky archaeologické a místopisné, 1900, roč. XIX, s. 156.

33 V Archivu Národního muzea jsou uloženy dva dokumenty: koncept dopisu o jmenování kustodem s platem $600 \mathrm{zl}$ ročně z 29. 2 .

1892 a Koulův dopis správnímu výboru z 30. 10. 1892

34 Koulovu instalaci zachycuje tištěný průvodce muzeem z roku 1917 ve zcela nezměněné podobě. Zůstala tak i nadále, včetně velkých světnicových vitrín, až do závěru třicátých let. a sběratele lidového umění. Stálá národopisná expozice, kterou společně s Kroužkem České chalupy v Národním muzeu vytvořil, byla první svého druhu u nás a přinesla do Prahy informace o lidovém umění v regionech. Při jejím vzniku Koula vycházel z modelu, který byl předurčen interiérem České chalupy, navázal na něj, zdokonalil jej pro muzejní potřeby a odborně zaštítil.

Sbírku historické archeologie uspořádal Jan Koula do jednotlivých materiálových skupin v tradičním pojetí zděděném ještě po kabinetech kuriozit. Nebyl muzejním vědcem-teoretikem, ale spíše zkušeným a nadšeným praktikem. Na rozdíl od Josefa L. Píče nenahlížel na sbírkové předměty jako na soubor hmotných pramenů, ale pojímal je jako zajímavé kolekce kulturně historických „starožitností“. Díky jeho akviziční politice však byly sbírkové fondy muzea doplňovány bohatým a unikátním materiálem. ${ }^{35}$

Sto let, které uplynuly $\mathrm{v}$ roce 2019 od úmrtí Jana Kouly, přineslo př́ležitost připomenout muže, jenž sehrál důležitou roli jak v historii Národního muzea, tak v dějinách českého muzejnictví. Muže, který ukončil vazby $s$ muzeem $\mathrm{v}$ roce 1917 svým odchodem, ale jehož jméno přesto zůstává s Národním

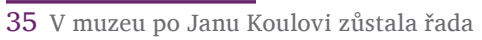
sbírkových předmětů, které aktivně vyhledal, zakoupil nebo do sbírek daroval. Historickoarcheologická sbírka vzrostla od jeho příchodu do roku 1917, kdy opustil muzeum, z několika set předmětů na 10000 čísel inventáře. Dodnes lze v kartotéce oddělení starších dějin nalézt desítky předmětů, které Jan Koula objevil a odprodal muzeu se záměrem doplnit některou z kolekcí. Jeho zkušenosti a fenomenální obrazová pamět mu pomáhaly vybírat pro muzeum skutečně jedinečné a pozoruhodné předměty. Koulou nově založená sbírka lidového umění čítala při jeho odchodu 3500 položek, celá řada předmětů pocházela z darů, které muzeu věnoval Koula, jeho manželka a členové Kroužku Ceské chalupy. Koula vedle výšivek a keramiky přenechal muzeu i řadu vlastních fotografií (skleněných negativů), které pořizoval od konce 80 . let. Jedná se o vzácné př́klady české etnografické fotografie $\mathrm{z}$ doby jejích počátků. muzeem a historií muzejní expozice natrvalo svázáno.

\section{SEZNAM PRAMENU゚ A LITERATURY}

Archiv Národního muzea v Praze, Registr Národního muzea.

Archiv architektury a stavitelství Národního technického muzea v Praze, fond č. 22 Jan Koula.

Literární archiv Památníku národního písemnictví v Praze, fond T. Nováková, fond $J$. Hlávka.

KOULA, Jan. Komentář k akvarelovým tabulím. Rukopis, 1919, nestr. (Soukromý majetek).

KOULA, Jan. Naše jubilejní výstava, VI. oddělení retrospektivní. Osvěta, 1891, roč. XXI, s. 946-956.

KOULA, Jan. O vývoji historického oddělení musea král. Českého. Sbírka histor. archaeologická. Památky archaeologické a místopisné, 1904, roč. XXI, s. 29-35.

KOULA, Jan E. O tatínkovi. Vzpomínky. Rukopis, 1965. (Soukromý majetek).

MERGLOVÁ PÁNKOVÁ, Lenka a Jan MERGL. Jan Koula novorenesančník a vlastimil. Plzeň: Západočeské muzeum v Plzni, 2019. ISBN 978-80-7247-162-1.

Národní listy, 1889, roč. XXIX, č. 188, 10. 7. 1889, s. 3.

PODLAHA, Antonín a Eduard ŠITTLER. Památky po sv. Václavu. Památky archaeologické a místopisné, 1900, roč. XIX.

Průvodce sbírkami Musea království Českého $v$ Praze. Praha, 1905.

SKLENÁŘ, Karel. Archeolog Josef Ladislav Píč jako muzejník v Národním muzeu. Časopis Národního muzea, 2013, roč. CLXXXII, s. 67-88.

STEHLÍKOVÁ, Dana. Waldes a ti druzí. Pražští sběratelé klenotů a obchodníci. In Sborník semináře k 100. výročí otevření Waldesova muzea. [Jablonec nad Nisou]: Muzeum skla a bižuterie v Jablonci nad Nisou - Praha: Kotěrovo centrum architektury, 2018, s. 26-31. ISBN 978-80-86397-32-0.

Sto let práce. Praha, 1891.

SVOBODA, S. F. Jan Koula musejní pracovník. Časopis Musea království 
Českého, Oddíl věd společenských, 1955 , roč. CXXIV, s. 171-176.

Valné shromáždění Společnosti musea roku 1894. Časopis Musea království Českého, 1894, roč. LXVIII, s. 1-49.

Valné shromáždění Společnosti musea roku 1895. Časopis Musea království Českého, 1895, roč. LXIX, s. 1-53.

Valné shromáždění Společnosti musea roku 1896. Časopis Musea království Českého, 1896, roč. LXX, s. 1-66.

WINTER, Tomáš a Pavla MACHALÍKOVÁ (eds.). Jdi na venkov! Výtvarné umění a lidová kultura $v$ českých zemích 1800-1960. Řevnice: Arbor vitae societas - Praha: Artefactum, 2019. ISBN 978-80-88256-10-6.

Zlatá Praha, 1889, roč. VI.

\section{LENKA MERGLOVÁ PÁNKOVÁ}

Západočeské muzeum v Plzni, Plzeň, Česká republika

Imerglova@zcm.cz

Lenka Merglová Pánková

absolvovala obor dějiny umění na

Ústavu dějin umění Filosofické

fakulty Univerzity Karlovy v Praze, pracovala do roku 2006 jako

kurátorka sbírky užitého umění v Muzeu Karlovy Vary, do roku 2017 jako odborná asistentka na Fakultě designu a umění Ladislava Sutnara Západočeské univerzity v Plzni, nyní v Západočeském muzeu v Plzni jako historička umění. Publikuje na téma užitého umění.
Lenka Merglová Pánková studied art history at the Department of Art History, Faculty of Arts of Charles University in Prague. Until 2006 she has worked as curator of the applied art collection in the Karlovy Vary Museum, until 2017 as a teaching fellow at the Ladislav Sutnar Faculty of Design and Art, University of West Bohemia in Pilsen. Today she is employed as art historian in the West Bohemian Museum in Pilsen. She publishes works on applied art. 